\title{
SITA JAMINAN DALAM KEPAILITAN
}

\author{
Sriti Hesti Astiti \\ sritihesti_astiti@ rocketmail.com \\ Hakim Pengadilan Negeri Kelas IB Gresik
}

\begin{abstract}
The law of bankruptcy basically has to pay more attention and give a proportionate legal protection between the interests of debtors to creditors, even also the interests of other creditors, who do not have a file in the bankruptcy process. Unfortunately, the legal protection for the other creditors which is regulated in Article 10 Law No. 37/2004 contains many weaknesses and give many erroneous interpretation in the field of its structure, culture and the substance. Therefore, the legal enforcement and the conservatoir measures in bankruptcy law which has been intended to protect the legal interests of what we called "the other creditors" in the commercial court decision becomes unpredictable.
\end{abstract}

Keyword : bankruptcy, other creditors, debtors.

\begin{abstract}
Abstrak
Lembaga hukum kepailitan pada dasarnya harus memperhatikan dan memberikan perlindungan hukum yang seimbang antara kepentingan debitor dengan kreditor, bahkan harus pula memperhatikan sungguh-sungguh kepentingan kreditor lain, yang tidak turut mengajukan perkara kepailitan. Namun sangat disayangkan, lembaga jaminan perlindungan hukum bagi kreditor yang diatur dalam Pasal 10 Undang-Undang No. 37 Tahun 2004 banyak mengandung kelemahan dalam praktik penegakan hukum yang bersifat struktur, kultur maupun substansi, sehingga mempengaruhi para praktisi hukum yang enggan menggunakannya. Akibatnya, dalam praktik penegakan hukum kepailitan yang bermaksud untuk melindungi kepentingan hukum kreditor di pengadilan niaga putusannya menjadi sulit diprediksi.
\end{abstract}

Kata Kunci : kepailitan, kreditor, debitor. 


\section{Pendahuluan}

Pada sesi perkuliahan mata kuliah Hukum dan Teori-Teori Keadilan, ada pertanyaan mengenai apakah hukum dan keadilan hakikatnya merupakan obyek yang satu atau terpisah? Bagaimana wajah hukum tanpa dilandasi oleh keadilan? Sebaliknya, bagaimana mengukur sebuah keadilan tanpa sarana hukum? dan tidak kalah penting adalah pertanyaan tentang apakah urgensi dan pentingnya kita mempelajari teori keadilan bagi pengembangan hukum? Pertanyaan - pertanyaan ini sangatlah menarik untuk dibahas meskipun sangat sulit pula untuk menjawabnya.Seperti diketahui, istilah keadilan senantiasa dipertentangkan dengan istilah ketidakadilan.Dimana ada konsep keadilan maka disitu pula ada konsep ketidakadilan. Biasanya kedua hal ini disandingkan, dan dalam konteks kajian hukum ada banyak contoh ketidakadilan merupakan anti tesis dari keadilan dalam bidang hukum, misalnya saja dalam kasus Prita, kasus pencurian sandal jepit, kasus nenek yang mencuri 3 (tiga) buah kakao, dan lain sebagainya.

Ukuran keadilan sebagaimana di singgung di atas sebenarnya menjangkau wilayah yang ideal atau berada dalam wilayah cita, dikarenakan berbicara masalah keadilan, berarti sudah dalam wilayah makna yang masuk dalam tataran filosofis yang perlu perenungan secara mendalam sampai hakikat yang paling dalam, bahkan Kelsen menekankan pada filsafat hukum Plato, bahwa keadilan didasarkan pada pengetahuan perihal sesuatu yang baik $^{1}$. Pengetahuan akan hal yang baik secara fundamental merupakan persoalan di luar dunia. Hal tersebut dapat diperoleh dengan kebijaksanaan.Pembahasan dalam makalah ini erat kaitannya dengan persoalan hukum dan keadilan, dimana salah satu cara mewujudkannya adalah dengan melakukan penegakan hukum sebaik baiknya. Adapun yang dimaksud sebaik-baiknya dalam penulisan ini adalah hendaknya penegakan hukum dilakukan secara professional oleh aparat penegak hukum, dengan cara menegakkan hukum yang tertuang dalam aturan-aturan melalui pemahaman yang cermat tanpa dilandasi oleh ego sektoral dari penegakan hukum itu sendiri.

Pada pertengahan tahun 1997, di beberapa negara di Asia, termasuk di Indonesia, terjadi gejolak moneter.Hal ini sangat berpengaruh pada kemampuan dunia usaha dalam mempertahankan kegiatan usahanya, termasuk dalam hal pememenuhan kewajiban pembayaran utang mereka pada para kreditornya. Keadaan seperti tersebut di atas, pada akhirnya menimbulkan krisis yang meluas ke berbagai sektor kehidupan sosial. Akibatnya, lahir pemikiran-pemikiran untuk secepatnya mengatasi krisis tersebut, dan mulai dipertanyakan bagaimanakah hukum dapat dimanfaatkan untuk mengatasi kesulitan ekonomi. Hal tersebut sesuai dengan teori Roscoe Pound yang mengatakan "Law as an instrument at social engineering”" hukum sebagai alat pembangunan masyarakat. ${ }^{2}$ Termasuk

\footnotetext{
1 W. Friedmann, Teori Dan Filsafat Hukum, Jakarta: PT Rajawali Press, 1990, h. 118.

2 Manahan M.P. Sitompul, "Syarat-Syarat Pernyataan Pailit Menurut Pasal 1 Ayat (1) UU No.4 Th. 1998 dan Penerapannya oleh Peradilan Niaga”, Universitas Sumatera Utara, Medan, 2001, h.1, dalam Roscoe Pound, An Introduction to the Philosophy of Law, New Edition, Yale University Press, 1972, h. 125.
} 
pemikiran mengenai peranan apa yang dapat dilakukan oleh hukum untuk membantu dunia usaha dalam mengatasi ketidakmampuan mereka untuk memenuhi kewajiban pembayaran utang yang besar mulai dikaji.

Salah satu langkah pembenahan di bidang hukum ekonomi untuk mengatasi masalah pembayaran utang adalah dengan cara membuat, merubah, menjelaskan dan menghapuskan sebagian pasal dari peraturan kepailitan (Faillissement verordening) yang diundangkan dalam Staatsblad tahun 1905 No.207 Jo Staatsblad tahun 1906 No.348 yang selanjutnya menetapkan berlakunya dengan Peraturan Pemerintah Pengganti Undang-Undang (PERPU) No.1 Tahun 1998 jo Undang-Undang No.4 Tahun 1998. Instrumen hukum tersebut diperlukan untuk memfasilitasi permasalahan hukum pembayaran utang dan permintaan pernyataan pailit. Maksud ditetapkannya PERPU No.1 Tahun 1998 jo Undang-Undang No.4 Tahun 1998 adalah untuk mengatasi gejolak moneter beserta akibatnya yang berakibat bagi perekonomian Indonesia saat ini. Lembaga hukum kepailitan diharapkan menjadi salah satu cara untuk menyelesaikan utang-piutang antara kreditor dan debitor secara adil, cepat dan efektif. Namun, akibat desakan untuk sesegera mungkin memperbaiki peraturan kepailitan maka ditempuh dengan cara tambal sulam pasal-pasal peraturan kepailitan yang ada. Akibatnya, "banyak ketentuan dalam pasal-pasal yang diubah, tidak sempurna". 3

Prinsip dasar hukum kepailitan sebenarnya berdasarkan pada ketentuan Pasal 1131 KUH Perdata. Pasal ini menyatakan bahwa semua barang, baik yang bergerak maupun yang tidak bergerak milik debitor, baik yang sudah ada maupun yang akan ada di kemudian hari menjadi jaminan bagi perikatan perorangan debitor tersebut.Tanggung jawab debitor berdasarkan ketentuan Pasal 1131 KUH Perdata inilah, yang akhirnya bermuara pada lembaga kepailitan. Sebab, dalam lembaga kepailitan sebenarnya mengatur bagaimanakah halnya jika seorang debitor tidak dapat membayar hutang-hutangnya, serta bagaimanakah pertanggungjawaban debitor tersebut, dalam kewenangannya dengan harta kekayaan yang masih atau akan dimilikinya.

Selain itu, maksud kepailitan pada dasarnya membagi-bagi hasil penjualan semua harta kekayaan debitor secara seimbang kepada semua kreditor, maka lembaga kepailitan hanya ada apabila debitor memiliki lebih dari seorang kreditor. Keberadaan lebih dari seorang kreditor ini dikenal dengan prinsip concursus creditorum. Jadi sesuai dengan rasio tersebut, tentunya debitor hanya dapat dinyatakan pailit, jika memiliki lebih dari seorang kreditor. Dari prinsip hukum yang demikian, maka dalam Undang-undang Kepailitan diharapkan ada suatu mekanisme hukum yang jelas dan dapat dijamin kepentingan hukum para kreditor, khususnya tentang tata cara dan hak kreditor untuk memperoleh kembali pembayaran piutangnya dari seorang debitor yang dinyatakan pailit.Hukum, sesuai dengan tujuannya haruslah berusaha memberikan keseimbangan dan keadilan. Oleh karena itulah bahwa

3 J. Djohansyah, "Makalah Hukum Asuransi yang Berkaitan Dengan Pelaksanaan Hukum Kepailitan Nasional", disampaikan pada Pendidikan dan Pelatihan Teknis Fungsional Peningkatan Profesionalisme Bagi Hakim Pengadilan Niaga, Tanggal 17 -21 Juni 2001, Jakarta. 
walaupun tujuan dari tulisan ini hendak meneliti tentang perlindungan hukum kreditor, maka yang perlu diperhatikan adalah apakah perlindungan hukum tersebut telah diberikan dalam proporsinya menurut keseimbangan yang pantas dan adil.Prinsip perlindungan hukum yang seimbang bagi kreditor disatu pihak serta bagi debitor di lain pihak diuraikan oleh Stefan A. Riesenfeld sebagai berikut :

The law of creditor's remedies has two principal set of goals: 1) To overcome recalcitrancy of the debtor who refusen to satisfy judgement againt him, to order collectibility by establishing priorities among completing creditors, and to prevent remove abstructions through improper dissipartion of assets; 2) To provide an orderly liquidation or rehabilitation of insolvent estates. ${ }^{4}$

Dalam perkara kepailitan, perlulah diperhatikan bahwa hukum harus mengupayakan untuk mengatasi keengganan para debitor untuk memenuhi kewajibannya, dengan cara menentukan tingkatan kreditor serta prioritas pembayaran terhadap piutang-piutangnya, dengan cara mengadakan tindakan-tindakan untuk mencegah para debitor menyingkirkan harta kekayaannya serta dengan mengadakan pengaturan tentang pemberesan terhadap harta kekayaan ataupun sampai rehabilitasi debitor. Oleh karena itu, didalamnya juga harus terdapat suatu jaminan agar debitor diperlakukan secara tidak semena-mena.

Untuk memberikan perlindungan hukum bagi kreditor, dalam hukum kepailitan diatur dalam Pasal 10 Undang-Undang No. 37 Tahun 2004 Tentang Kepailitan Dan Penundaan Kewajiban Pembayaran Utang (selanjutnya disebut UU No. 37/2004) yang pada pokoknya berisi diperkenankannya mengajukan permohonan sita jaminan oleh kreditor ataupun menunjuk kurator sementara untuk mengelola atas sebagian atau seluruh kekayaan debitor, sebagai upaya pengamanan yang bersifat preventif dan sementara, yakni untuk mencegah kemungkinan bagi debitor melakukan tindakan terhadap kekayaannya sehingga dapat merugikan kepentingan kreditor dalam rangka pelunasan utangnya. Selanjutnya dalam ketentuan Pasal 10 ayat (3) UU No. 37/2004 juga diatur, apabila permohonan sita jaminan tersebut dikabulkan, Pengadilan Niaga dapat mensyaratkan agar kreditor memberikan jaminan dalam jumlah yang wajar demi menjaga keseimbangan antara kepentingan debitor dan kreditor.

Oleh karena itulah yang perlu dikaji adalah dalam hal menentukan jumlah jaminan, siapakah yang menjalankan sita jaminan tersebut, bagaimanakah melaksanakannya serta apa akibat hukumnya, dan lain-lain yang kesemuanya itu tidak diatur dalam UU No. 37/2004 tersebut. Oleh karena itu dalam praktik diberlakukan ketentuan Pasal 197, 198 dan 199 HIR (211, 212, dan 213 RBG). Begitu pula bagaimana halnya, bila ada perlawanan terhadap sita jaminan tersebut, akan menimbulkan masalah hukum apakah perkara tersebut diperiksa di Pengadilan Niaga ataukah di Pengadilan Negeri, perlu ada kejelasan. Dari uraian di atas, maka dapatlah disimpulkan pokok kajian yang akan dibahas adalah beberapa masalah sita

4 HR. Purwoto S. Gandasubrata, "Renungan Hukum”, Mahkamah Agung RI Jakarta, 1998, h. 295396, dalam Stefan A.Riesenfeld, Creditor's Remendies Debtor's Protection, Minnesota USA: West Publishing Company, St. Paul, 1980. 
jaminan dalam praktik permohonan pernyatan pailit di Pengadilan Niaga, tentang pengaturan dan pelaksanaan sita jaminan dalam praktik permohonan pernyataan pailit di Pengadilan Niaga. Selain itu apakah sistem perlindungan hukum bagi kreditor dapat berjalan dengan baik dalam praktik penjatuhan pailit di Pengadilan Niaga dan juga apakah sistem pengaturan perlindungan hukum kreditor sebelum penjatuhan pailit di Pengadilan Niaga, mempengaruhi perilaku hakim dan ataupun kreditor untuk mempergunakan lembaga hukum sita jaminan sebagai ketentuan perlindungan hukum kreditor di Pengadilan Niaga.

\section{Pengertian dan Prinsip Dasar Kepailitan}

Kepailitan adalah suatu penyitaan yang dilaksanakan oleh pengadilan dan mengeksekusi semua harta kekayaan debitor demi kepentingan para kreditor bersama. ${ }^{5}$ Kepailitan merupakan suatu penyitaan umum atas seluruh kekayaan debitor untuk kepentingan kreditor secara bersama-sama. Menurut Victor M. Situmorang dan Hendri Sukarso, pailit hanya mengenai kekayaan dan tidak mengenai pribadi dari orang yang dinyatakan pailit (debitor). Faillisement adalah suatu usaha bersama untuk mendapatkan pembayaran bagi semua orang berpiutang secara adil. ${ }^{6}$

Pengertian Kepailitan ditegaskan dalam UU No. 37/2004 sebagai "sita umum atas semua harta kekayaan debitor". Sebelumnya dalam PERPU No. 1 Tahun 1998 jo UU No. 4 Tahun 1998, pengertian kepailitan berkaitan dengan syarat-syarat kepailitan dan tidak ada pengertian yang bersifat definisional. Jadi kepailitan merupakan eksekusi massal yang ditetapkan dengan keputusan hakim, yang berlaku serta merta.

Dengan melakukan penyitaan umum atas semua harta orang yang dinyatakan pailit, baik yang ada pada waktu pernyataan pailit, maupun yang diperoleh selama kepailitan berlangsung, untuk kepentingan semua kreditor, yang dilakukan dengan pengawasan pihak yang berwenang, sehingga sesungguhnya kepailitan tertujuan untuk: a) Mencegah penyitaan dan eksekusi yang dimintakan oleh kreditor secara perorangan; b) Ditujukan hanya mengenai harta benda debitor, bukan pribadinya. Sehingga, debitor tetap cakap untuk melakukan perbuatan hukum di luar hukum kekayaan. ${ }^{7}$

Sebagai perbandingan dalam Australian Bankrupcy Law, tujuan kepailitan dinyatakan: when a person is unable to pay her or his debts and is in a hopeless financial position, the law should enable proceedings to be taken, either by the debtors or by a creditor, so that most kinds of the debtor's property can be taken and used to pay the creditors in proportion to the amounts owed to each of them. ${ }^{8}$

\footnotetext{
5 Lee Aweng, Op.Cit. h.1 dalam Polak-polakk: "Faillissement en Surseance van Betaling, doel I, tweede gedeelte, zesde ruk, wolters-Noordhoft, N.V. Groningen, 1969.

6 Victor M. Situmorang, Hendri Sukarso, Pengantar Hukum Kepailitan di Indonesia, Jakarta: Rineka Cipta, 1994, h. 11.

7 Bandingkan dengan Bernadette Waluyo, Hukum Kepailitan dan Penundaan Kewajiban Pembayaran Utang, Mandar Maju, Bandung: 1999, h. 1.

8 Dennis Rose, QC, Australian Bankrupcy Law, 10th Edition, The Law Book Company Ltd, 1994, h.1.
} 
Lembaga kepailitan merupakan suatu sistem yang mengatur bagimanakah hukum harus bertindak manakala seorang debitor tidak dapat membayar hutang-hutangnya, dan bagaimanakah pertanggungjawaban debitor tersebut, dalam hubungannya dengan harta kekayaan yang masih atau akan dimilikinya. Dilakukan penyitaan secara massal dimaksudkan untuk menghindari para kreditor bertindak sendiri-sendiri, agar semua kreditor memperoleh manfaat dari harta kekayaan debitor pailit, dengan cara dibagi menurut perimbangan hak tagihan atau tuntutan mereka masing-masing.

Lembaga kepailitan merupakan wujud dari pelaksanaan ketentuan pasal 1131 jo 1132 KUH Perdata. Dalam Pasal 1131 KUH Perdata ditentukan bahwa semua harta kekayaan debitor baik benda bergerak atau tidak bergerak, baik yang sekarang maupun yang akan diperolehnya menjadi tanggungan atas perikatan-perikatan pribadinya. Sedangkan Pasal 1132 KUH Perdata menentukan bahwa benda-benda dimaksud sebagai jaminan bagi para kreditor secara bersama-sama hasil penjualan benda-benda tersebut dibagi antara kreditor bersama-sama menurut perbandingan atau imbangan tagihan-tagihan mereka, kecuali diantara para kreditor tersebut terdapat alasan-alasan untuk diistimewakan (didahulukan) secara sah menurut hukum.

Putusan pernyataan pailit harus dilakukan oleh Pengadilan (Hakim) yang berwenang untuk menjatuhkan pernyataan pailit (sekarang hakim Pengadilan Niaga). Oleh karena itulah hukum kepailitan memiliki karakter sebagai hukum publik bukan hukum privat. Walaupun kepailitan berawal dari Pasal 1131 KUH Perdata, tidaklah berarti bahwa ketentuan hukum kepailitan memiliki sifat sebagai hukum privat. Sebab ketentuan Pasal 1131 KUH Perdata, sekalipun harus diakui merupakan ketentuan hukum perdata, sesuai doktrin karena merupakan bagian dari buku kedua Kitab Undang-Undang Hukum Perdata merupakan ketentuan yang bersifat memaksa (baca: publik) dan tidak dapat disimpangi, sekalipun atas kesepakatan para pihak. ${ }^{9}$

Sisi hukum perdata formil dari lembaga kepailitan melahirkan hukum acara perdata yang mengatur proses penjatuhan pailit, dan inilah yang menegaskan karakter hukum publik dari hukum kepailitan. Sebab, hukum acara perdata merupakan bagian dari hukum publik.Secara teoritis, oleh karena hukum kepailitan bersifat publik, maka dieperlukan suatu peraturan yang terinci bagi setiap langkah proses permohonan pernyataan pailit. Akibat dijatuhkan putusan pailit, maka demi hukum telah terjadi sita umum (massal) atas seluruh harta kekayaan debitor. Konsekuensinya, bahwa sita individu yang diletakkan sebelumnya atas harta kekayaan debito otomatis terangkat. Namun yang perlu dipahami dengan dijatuhkannya pailit, si pailit tidak memiliki wewenang lagi melakukan tindakan kepengurusan dan pemilikan atas harta kekayaannya. Tetapi kepailitan hanya menyangkut tentang kepengurusan harta kekayaannya dan bukan masalah kewenangan pribadinya. Artinya,

9 Setiawan, "Kepailitan Konsep-Konsep Dasar Serta Pengertiannya”, Kumpulan Makalah Calon Hakim Pengadilan Niaga, Mahkamah Agung RI, Jakarta, h. 59 dikutip dari Varia Peradilan, IKAHI-MARI, Jakarta, No.156 September 1998. 
si pailit tetap cakap untuk melakukan perbuatan hukum diluar hukum kekayaan. Kepailitan tidak menghilangkan sama sekali kewenangan si pailit untuk melakukan pengurusan dan pemilikan harta yang berhubungan dengan pribadinya sebagaimana disebutkan dalam Pasal 22 UU No. 37/2004. Dan tindakan-tindakan yang membawa akibat-akibat hukum atas harta kekayaan si pailit, hanya dapat dilakukan oleh kurator yang ditunjuk hakim dalam putusan pailit.

Dalam Penjelasan Umum UU No. 37/2004 disebutkan bahwa terdapat 3 (tiga) alasan lahirnya UU Kepailitan, yaitu: a) Untuk menghindari perebutan harta debitor apabila dalam waktu yang sama ada beberapa kreditor yang menagih piutangnya pada debitor; b) Untuk menghindari adanya kreditor pemegang hak jaminan kebendaan yang menuntut haknya dengan cara menjual barang debitor tanpa memperhatikan kepentingan debitor atau para kreditor lainnya; c) Untuk menghindari kecurangan yang dilakukan oleh salah seorang kreditor atau debitor sendiri. Misalnya, debitor berusaha memberi keuntungan kepada seorang atau beberapa prang kreditor tertentu sehingga kreditor lainnya dirugikan. Selain itu, debitor mungkin saja dapat melarikan semua harta kekayaannya dengan maksud untuk melepaskan tanggung jawabnya kepada para kreditor.

Hal penting yang perlu diperhatikan dalam masalah kepailitan adalah penggunaan istilah insolvency yang sering dipersamakan dan dipertukarkan pemakaiannya dengan bankruptcy. Sesungguhnya, penggunaan istilah tersebut perlu diluruskan. Kata insolvency dalam sistem hukum common law berbeda maknanya dengan kata insolvensi yang berasal dari istilah Belanda "insolventie", yang digunakan dalam sistem hukum kepailitan Indonesia. Pada common law system insolvency artinya sama dengan bankruptcy, "namun istilah insolvency digunakan bagi badan hukum atau company, sedangkan bankruptcy digunakan khusus terhadap individu". ${ }^{10}$ Sedangkan, insolvency dalam pengertian hukum kepailitan Indonesia adalah mengandung makna keadaan berhenti membayar, yang terjadi setelah rapat verifikasi para kreditor setelah adanya putusan pernyataan pailit. Makna teknis insolvensi sesuai ordonansi kepailitan tahun 1905 sebenarnya adalah suatu periode setelah dijatuhkannya putusan kepailitan yang tidak diikuti dengan perdamaian (accord) diantara para kreditornya ataupun perdamaian telah ditolak dengan pasti. ${ }^{11}$

Jadi dalam sistem hukum anglosaxon atau common law, insolvensi itu terjadi sebelum dijatuhkan putusan pailit, sedangkan dalam sistem hukum civil law (Eropa Kontinental) insolvensi itu terjadi setelah kepailitan. Bahwa kepailitan atau bankrupcy menurut hukum Inggris (common law system) senantiasa didahulukan dengan keadaan tidak mampu membayar (insolvent) dimana keadaan insolvent tersebut harus terlebih dahulu dinyatakan oleh pengadilan (judicial declaration) untuk dapat dimintakan pernyataan keadaan pailit

10 Elyta Ras Ginting, "Usulan Penelitian Kedudukan Kreditor Separatis Dalam Perkara Kepailitan", Medan: USU, 2002, h. 15 dikutip dari Tony Wales, Pocket Law.

11 Setiawan, Op.Cit, h. 94. 
(banckrupt) oleh pengadilan. ${ }^{12}$ Setelah debitor dinyatakan pailit oleh putusan hakim Pengadilan Niaga, maka debitor tidak dapat dan tidak boleh lagi mengurus harta kekayaannya, sehingga pengurusan harta kekayaannya tersebut dilakukan oleh kurator dan diawasi oleh Hakim Pengawas. Namun dalam sistem Hukum Kepailitan Indonesia sebagaimana diatur dalam Pasal 10 UU No. 37/2004 selama proses pemeriksaan kepailitan berlangsung sebelum dijatuhkannya putusan pailit dapat diangkat kurator sementara.

\section{Perlindungan Hukum Sebelum Putusan Pernyataan Pailit Dijatuhkan}

Berdasarkan ketentuan pasal 10 Undang-Undang No. 37/2004 maka ada 3 (tiga) hal yang harus diperhatikan hakim untuk memberikan perlindungan hukum kreditor dengan menggunakan lembaga sita jaminan dalam kepailitan yaitu: 1) Permohonan tersebut hanya dapat dikabulkan, apabila masalah tersebut diperlukan untuk melindungi kepentingan kreditor; 2) Hal tersebut merupakan upaya pengamanan yaitu sebagai upaya yang bersifat preventif dan sementara, dan mencegah kemungkinan debitor melakukan tindakan terhadap harta kekayaannya, sehingga dapat merugikan kepentingan kreditor dalam rangka pelunasan utangnya; 3) Apabila permohonan tersebut dikabulkan, maka pengadilan dapat menetapkan syarat agar kreditor pemohon memberikan jaminan sejumlah uang yang dianggap wajar oleh pengadilan.

Disisi lain, tentang adanya penunjukan kurator sementara sebagaimana dimaksudkan dalam Pasal 10 ayat (1) sub b, adalah untuk melakukan pengawasan terhadap debitor, khususnya dalam hal: 1) Pengelolaan usaha debitor; 2) Pembayaran kepada kreditor; 3) Pengalihan harta debitor; 4) Penjaminan debitor. ${ }^{13}$ Dalam hal ini diperlukan adanya kurator sementara, karena sebelum dijatuhkan putusan pailit, debitor belum pailit dan berwenang mengelola harta kekayaannya. Untuk menghindari, debitor mengalihkan harta kekayaannya, maka perlu dilakukan pengawasan dan hal tersebut menjadi tugas kurator sementara. Pada prinsipnya tugas kurator sementara ini, lebih terbatas dibandingkan tugas-tugas kurator tetap. Kurator sementara hanya bertugas sebagai supervisor. ${ }^{14}$

Sesungguhnya proses penanganan perkara kepailitan yang diperiksa dan diadili di pengadilan niaga sesungguhnya sangatlah sulit dan pelik, akan tetapi lembaga ini sangat banyak digunakan ketika terjadi krisis ekonomi. Walaupun kini untuk tiap tahunnya jumlah perkaranya cenderung menurun, namun permasalahan yang timbul terus meningkat. Sesungguhnya semula diperkirakan dengan dibentuknya pengadilan niaga di Jakarta, dan beberapa daerah lainnya, jumlah perkara kepailitan akan mencapai ribuan perkara. Namun ternyata dugaan tersebut meleset dari yang diperkirakan. Beberapa faktor penyebab minimnya perkara kepailitan yang diperiksa dan diadili oleh pengadilan niaga secara umum dapat direka, karena adanya hal-hal sebagai berikut; a) Faktor ekonomis, bahwa para kreditor

\footnotetext{
12 Elyta Ras Ginting,Op. Cit, h. 16.

13 Munir Fuady, Op. Cit., h. 62.

14 Ibid.
} 
menyadari belum saatnya memohon kepailitan jika nilai beli masyarakat masih terlalu rendah untuk membeli (lelang) asset pailit; b) Faktor sosial, bahwa beberapa kreditor bersikap hatihati untuk menuntut kepailitan yang bisa berdampak timbulnya pengangguran; c) Faktor pelayanan hukum, bahwa proses penanganan sengketa niaga masih tergolong lamban dan bahkan ada beberapa putusan hakim yang terkesan kontradiktif dan unpredictable. ${ }^{15}$

Prinsip bahwa dalam perkara kepailitan harus dilakukan atau diselesaikan secara adil, dalam arti memperhatikan kepentingan debitor atau kepentingan kreditor secara seimbang telah menjadi yurisprudensi yakni putusan Mahkamah Agung RI No.42 PK/N/1999 tanggal 4 Nopember 1999 dalam perkara PT. Citra Jombaran Indah Hotel melawan S. Sangyong Engineering \& Construction Co. Ltd. Pertimbangan hukum putusan Mahkamah Agung tersebut, antara lain menyebutkan bahwa penerapan kepailitan harus dilakukan/diselesaikan secara adil dalam arti memperhatikan kepentingan perusahaan sebagai debitor atau kepentingan kreditor secara seimbang. Potensi dan prospek dari usaha debitor harus ada diperhitungkan secara baik. Juga debitor masih mempunyai potensi dan prospek, sehingga merupakan tunas-tunas yang masih dapat berkembang. Seharusnya masih diberi kesempatan untuk hidup dan berkembang. Oleh karena itu penjatuhan pailit merupakan ultimum remedium. ${ }^{16}$

Berdasarkan pertimbangan hukum tersebut jelas bahwa pengertian perlindungan hukum dalam perkara kepailitan haruslah dilakukan secara proporsional dengan memperhatikan kepentingan kreditor termasuk kreditor lainnya yang tidak ikut menginginkan perkara kepailitan dan debitor secara seimbang. Sebagaimana diketahui, sejak dijatuhkannya putusan pailit, maka sejak saat itu debitor kehilangan hak untuk melakukan pengurusan dan penguasaan harta bendanya (persona stand in indicio). Pengurusan dan penguasaan harta benda tersebut akan beralih ke kurator (Balai Harta Peninggalan - BHP). Si pailit hanya diperkenankan untuk melakukan perbuatan hukum di bidang harta kekayaan sepanjang hal tersebut menguntungkan harta (boedel) pailit.

Berdasarkan hal tersebut, tentunya menimbulkan kekuatiran bagaimanakah halnya kalau debitor sebelum dinyatakan pailit, telah melakukan tindakan-tindakan yang dapat merugikan kreditor.Memperhatikan rumusan Pasal 10 UU No. 37/ 2004 tersebut di atas, telah diatur upaya pengamanannya manakala debitor nakal dengan menghilangkan dan atau menyembunyikan harta kekayaannya. Selanjutnya dalam bagian penjelasannya, dijelaskan bahwa upaya pengamanan sebagaimana dimaksud dalam ketentuan bersifat preventif dan sementara, dan dimaksudkan untuk mencegah kemungkinan bagi debitor melakukan tindakan terhadap kekayaannya sehingga dapat merugikan kepentingan kreditor dalam rangka pelunasan utangnya.

15 MP. Sitompul, Op.Cit., h. 57 dikutip dari HP. Panggabean, Persepektif Kewenangan Pengadilan Niaga di Indonesia (Dampak perkembangan hukum di Indonesia, makalah diskusi hukum di FH-UGM, Jogyakarta, 22 September 2000, h. 1.

16 Yurisprudensi Mahkamah Agung RI, Tahun 2000, MARI, Jakarta, h. 175. 
Namun demikian, untuk menjaga keseimbangan antara kepentingan debitor dan kreditor, Pengadilan dapat mensyaratkan agar kreditor memberikan jaminan dalam jumlah yang wajar apabila upaya pengamanan tersebut dikabulkan. Dalam menetapkan persyaratan tentang jaminan tersebut, Pengadilan antara lain harus mempertimbangkan ada tidaknya jaminan atas keseluruhan kekayaan debitor, jenis kekayaan debitor dan besarnya jaminan yang harus diberikan dibandingkan dengan kemungkinan besarnya kerugian yang diderita oleh debitor apbila pemohon pernyataan pailit ditolak Pengadilan.

\section{Praktik Pelaksanaan Sita Jaminan Sebagai Perlindungan Hukum Kreditor dalam Kepailitan}

Sampai bulan Agustus tahun 2008 di seluruh pengadilan niaga, belum pernah dilaksanakan ketentuan Pasal 10 UU No. 37/2004 dimaksud. Padahal, dalam permohonan pernyataan pailit, biasanya selalu juga dicantumkan permohonan sita jaminan dalam perkara permohonan kepailitan. Bahkan dalam praktik selama ini, adanya permohonan sita jaminan tersebut, biasanya tidak dipertimbangkan secara khusus dalam putusan pernyataan kepailitan, karena dengan dijatuhkannya putusan pailit maka demi hukum harta benda (boedel) si pailit menjadi sita umum.

Banyak hambatan dan kesulitan dalam menerapkan pelaksanaan memberikan jaminan perlindungan hukum kepada kreditor dengan menggunakan lembaga sita jaminan selama proses penjatuhan pailit. Hambatan tersebut, sebenarnya telah didiskusikan dalam berbagai pelatihan teknis yustisial bagi para hakim niaga di seluruh Indonesia. Namum, belum mendapat suatu pemecahan yang memuaskan.

Pada pokoknya, hambatan-hambatan yang ditemukan dapat dibagi dalam 3 (tiga) golongan besar, yang meliputi aspek struktur, kultur (budaya) dan substansi (materi) ketentuan tersebut. Pertama adalah hambatan dari segi struktur, meliputi: 1) Pengadilan niaga, sebagai peradilan khusus di lingkungan peradilan umum belum ada kejelasan struktur, wewenang maupun pembinaan aparaturnya; 2) Prosedur untuk menetapkan adanya sita jaminan, pengangkatan kurator sementara, dan penentuan jumlah uang jaminan yang wajar belum jelas dan tidak ada peraturan pelaksananya; 3) Waktu untuk pelaksanaan sita jaminan dalam upaya perlindungan hukum bagi kreditor relatif terlalu singkat; 4) Adanya ketentuan pembayaran uang jaminan dirasakan terlalu berat; 5) Layanan pengadilan niaga terhadap hal tersebut belum memuaskan; 6) Pemeriksaan asset debitor yang akan disita dan ataupun diperhitungkan untuk menentukan uang jaminan, memerlukan waktu yang lama.

Hambatan kedua adalah hambatan dari segi kultur seperti: 1) Para pelaku usaha (kreditor dan debitor) masih belum memahami maksud dan tujuan kepailitan, sehingga masih takut menggunakan lembaga hukum tersebut; 2) Berbagai faktor sosial menjadi penghalang untuk meletakkan sita jaminan, pengangkatan kurator sementara dan ataupun menentukan uang jaminan; 3) Proses pelayanan hukum dan kinerja aparatur di lingkungan pengadilan 
niga masih dinilai lamban dan belum tumbuhnya kepercayaan bahwa pengadilan niaga akan mengadili dengan transparan, efisien dan efektif sesuai keadilan hukum dan kebenaran. Ketiga adalah hambatan substansi, meliputi: 1) Ketentuan-ketentuan yang mengatur lembaga sita jaminan, pengangkatan kurator sementara dan penentuan jumlah uang sebagai jaminan yang wajar masih belum jelas, bahkan tidak ada peraturan pelaksanannya; 2) Sulit untuk membuktikan dengan pembuktian yang sederhana, bahwa debitor sudah melakukan tindakan-tindakan yang dapat merugikan kepentingan kreditor.

Berdasarkan data pendapat para praktisi dan pengguna lembaga hukum kepailitan, dapatlah disimpulkan bahwa ketentuan jaminan perlindungan hukum sebelum putusan pailit dijatuhkan sebagaimana diatur dalam Pasal 10 UU No. 37 Tahun 2004 masih banyak mengalami hambatan, terutama disebabkan oleh terbatasnya (minimnya) waktu yang tersedia, dan juga ketentuan dimaksud dipandang terlalu samar, dan belum adanya peraturan pelaksanaanya lebih lanjut mengakibatkan berbagai kesulitan dan hambatan. Disamping itu adanya ketentuan bahwa adanya persyaratan memberikan jaminan dalam jumlah yang wajar oleh kreditor, dianggap sebagai hambatan tersendiri, karena tidak jelas bagaimana cara penentuannya, bagi para kurator tugas sebagai kurator sementara yang pengaturannya tidak jelas dan terinci sangatlah menyulitkan mereka, apalagi mereka harus bertanggung jawab secara pribadi apabila ada kesalahan pengurusan yang menyebabkan nilai asset (boedel) menjadi berkurang karena keteledorannya.

Mariana Sutadi Wakil Ketua Mahkamah Agung Bidang Yudisial berpendapat bahwa apabila permohonan sita jaminan dikabulkan, pengadilan niaga dapat mensyaratkan agar kreditor memberikan jaminan dalam jumlah yang wajar demi menjaga keseimbangan antara kepentingan kreditor dan debitor. Siapa yang menjalankan sita jaminan tersebut dan bagaimana melaksanakannya serta apa akibat hukumnya tidak diatur dalam Pasal 7 Perpu No. 1 Tahun 1998 jo UU No. 4 Tahun 1998 kini Pasal 10 UU No. 37/2004 -penjelasan oleh penulis- karenanya ketentuan dalam Pasal 197, 198 dan 199 HIR, harus diterapkan. Sita jaminan dijalankan oleh panitera pengadilan negeri dan bila ia berhalangan dapat digantikan oleh seorang yang cakap atau yang dapat dipercaya yang akan ditunjuk oleh ketua pengadilan negeri. Sita jaminan tidak boleh diletakkan atas hewan dan perkakas yang sungguh-sungguh berguna bagi tersita untuk menjalankan pencahariannya sendiri. ${ }^{17}$

Pengadilan niaga adalah pengadilan dalam lingkungan peradilan umum yang berwenang untuk memeriksa dan memutus permohonan pernyataan pailit dan permohonan penundaan kewajiban pembayaran utang, serta perkara lain di bidang perniagaan yang penetapannya akan dilakukan sesuai dengan ketentuan peraturan-perundang-undangan yakni Pasal 300 UU No. 37/2004. Sebagai suatu pengadilan khusus dalam lingkungan peradilan umum, sesuai dengan Pasal 8 Undang-Undang Nomor 2 Tahun 1986 tentang Peradilan

17 Mariana Sutadi, "Hukum Acara Pada Pengadilan Niaga", dalam pelatihan teknis yustisial bagi hakim niaga di Malang, tanggal 15 Desember 1999. 
Umum sebagaimana telah diubah dengan Undang-Undang Nomor 8 Tahun 2004 tentang Perubahan Atas UU No. 2 Tahun 2006 tentang Peradilan Umum (Selanjutnya disebut UU Peradilan Umum), susunan; kekuasaan dan hukum acara pengadilan niaga diatur dalam undang-undang, yakni. Namun dengan belum terbentuknya undang-undang yang mengatur perkara lain di bidang perniagaan yang juga termasuk dalam kewenangan pengadilan niaga, maka lingkup kewenangan pengadilan niaga terbatas pada kewenangan secara substantif ditentukan dan diatur dalam pasal 300 UU No. 37/2004 yaitu masalah permohonan pernyataan pailit dan penundaan kewajiban pembayaran utang.

Akibat pandangan yang demikian, tentunya permasalahan-permasalahan hukum yang timbul sehubungan dengan pelaksanaan sita jaminan, pengangkatan kurator sementara ataupun penentuan jumlah jaminan yang dianggap wajar sebagaimana diatur dalam Pasal 10 UU No. 37/2004, umpamanya perlawanan terhadap sita jaminan, harus diperiksa dan diadili di pengadilan umum (pengadilan negeri), bukan di pengadilan niaga, karena hal tersebut menjadi jurusdiksi (kewenangan) pengadilan negeri. Sebagaimana dikemukakan di bagian awal, sesungguhnya persoalan ini telah dijadikan bahan diskusi diantara praktisi hukum, khususnya di kalangan para hakim niaga. Dari berbagai hambatan yang telah dikemukakan tersebut kini akan diikaji beberapa permasalahan mendasar, untuk mengetahui mengapa ketentuan yang sangat penting tersebut tidak pernah sekalipun dilaksanakan.

\section{Jaminan Perlindungan Hukum bagi Kreditor Sangat Diperlukan, Namun Waktu yang Tersedia Sangat Terbatas.}

Para praktisi hukum (hakim niaga, penasihat hukum, dan kurator) berpendapat lembaga jaminan perlindungan hukum kreditor sebagaimana diatur dalam Pasal 10 UndangUndang No. 37/2004 masih diperlukan dalam perkaran kepailitan. Bahkan beberapa diantaranya berpendapat perlu juga dibuka suatu lembaga hukum yang dapat memberikan kemungkinan agar selama proses kepailitan berlangsung dapat juga dilakukan tindakan penyegelan atau harta kekayaan debitor ataupun dilakukan penyanderaan atas debitor yang terbukti tetap melakukan tindakan-tindakan yang dikuatirkan dapat menggelapkan harta kekayaannya, sehingga dapat merugikan kreditor.

Kebutuhan agar para kreditor dapat segera mendapatkan jaminan atas pembayaran piutangnya, dan kekuatiran bahwa debitor dengan segala cara akan menyingkirkan harta kekayaannya, menjadi alasan diperlukannya lembaga hukum yang dapat memberikan jaminan perlindungan hukum bagi kreditor. Memperhatikan limit waktu penyelesaian perkara di pengadilan niaga yang ditentukan dalam Pasal 8 ayat (5) UU No. 37/2004 bahwa putusan atas permohonan pernyataan pailit harus ditetapkan dalam jangka waktu paling lambat 60 (enam puluh) hari terhitung sejak tanggal permohonan pernyataan pailit didaftarkan. Ketentuan ini, mengakibatkan pelaksanaan perlindungan hukum bagi kreditor sebagaimana ditentukan dalam Pasal 10 UU No. 37/2004 sangat sulit dilaksanakan. Hal ini 
disebabkan, walaupun ketentuan Pasal 10 Undang-Undang No. 37 Tahun 2004 menentukan bahwa permohonan tersebut hanya dapat dikabulkan, apabila hal tersebut diperlukan guna melindungi kepentingan kreditor, namun hakim harus arif dan bijaksana untu dapat mengabulkan permintaan tersebut, karena ia harus memperhatikan keseimbangan antara kewajiban-kewajiban hukum kreditor dan debitor secara proporsional selama proses pemeriksaan kepailitan berlangsung.

Berdasarkan hal tersebut, maka patulah disambut gembira perubahan tentang penetapan lamanya jangka waktu pemeriksaan kepailitan di pengadilan niaga, dalam undangundang kepailitan yang baru, telah memuat perubahan, bahwa pada umumnya untuk jangka waktu penyampaian berkas perkara dari panitera atau ketua pengadilan ditambah satu hari atau dilipatkan menjadi dua kali, antara lain 2 hari, setelah didaftar permohonan pernyataan pailit disampaikan kepada ketua pengadilan dan 3 hari setelah tanggal permohonan ditetapkan hari sidang serta penetapan putusan pernyataan pailit paling lambat 60 hari setelah permohonan didaftarkan.

\section{Peraturan Perlindungan Hukum bagi Kreditor Dalam Perkara Kepailitan Menimbulkan Bias Penafsiran}

Ketentuan yang dimaksudkan untuk memberikan perlindungan hukum bagi kreditor sebagaimana diatur dalam Pasal 10 UU No. 37/2004 tersebut, ternyata, hanya mengambil alih seluruh ketentuan yang terdapat dalam Pasal 7 PERPU No.1 Tahun 1998 jo Undang-Undang No.4 Tahun 1998. Perubahan yang dilakukan adalah hanya merubah para pihak yang dapat mengajukan permohonan sita jaminan dan ataupun pengangkatan kurator sementara, kalau semula dirumuskan pihak yang dapat mengajukan hal tersebut adalah disebutkan kejaksaan dan atau kreditor, kini lebih dirinci menjadi beberapa pihak, yaitu selain kejaksaan dan kreditor juga disebutkan pula Menteri Keuangan, Badan Pengawas Pasar Modal (BAPEPAM), dan Bank Indonesia. Perubahan semacam itu tentunya tidak akan mengefektipkan pelaksanannya, karena permasalahan utamanya adalah bagaimana mengatasi kelemahan undang-undang agar dapat dilaksanakan, disamping itu harus ada suatu kejelasan siapakah yang berwenang untuk mengadilinya manakala timbul persengketaan akibat pelaksanaan dari ketentuan tersebut. Berdasarkan pertimbangan tersebut ketentuan-ketentuan tentang cara bagaimana jaminan perlindungan kreditor mesti dilakukan, dan berbagai sengketa yang melingkupinya harus diatur secara jelas, dan terinci.

\section{Biaya Untuk Memberikan Jaminan Perlindungan Hukum bagi Kreditor Dalam Kepailitan Relatif Tinggi}

Biaya yang harus dibayar untuk perkara kepailitan, memang dirasakan cukup besar, walaupun hal itu dapat dipahami karena tugas pekerjaan yang harus dilakukan memang sangat berat dan rumit. Beberapa peraturan yang berhubungan dengan biaya dalam pengajuan 
permohonan kepailitan yaitu: 1) Peraturan Pemerintah Republik Indonesia Nomor 26 Tahun 1999 jo PP No. 19 Tahun 2007 tentang Tarif Atas Jenis Penerimaan Negara Bukan Pajak yang berlaku pada Departemen Kehakiman; 2) Keputusan Menteri Kehakiman Republik Indonesia Nomor:M.02-UM.01.06 Tahun 1993 tentang Penetapan Biaya Pelayanan Jasa Hukum di Lingkungan Kantor Balai Harta Peninggalan Departemen Kehakiman; 3) Keputusan Menteri Kehakiman Republik Indonesia Nomor : H.09-HT.05.10- Tahun 1998 tentang Pedoman Besarnya Imbalan Jasa Bagi Kurator dan Pengurus; 4) Surat Keputusan Ketua Pengadilan Negeri/Niaga Jakarta Pusat Nomor: 007.DC.HT.048.01/VIII/1998/01 tentang Biaya-Biaya Pendaftaran Perkara Kepailitan di Kepaniteraan Pengadilan Negeri/ Niaga Jakarta Pusat.

Biaya yang harus diperhatikan dan mesti dibayar oleh pemohon kepailitan apabila hendak mengajukan perkara kepailitan meliputi: a) Biaya untukjasa seorang penasihat hukum, karena untuk beracara di pengadilan niaga harus diwakili oleh seorag penasihat hukum (Pasal 6 Undang-Undang No.37 Tahun 2004); b) Biaya pendaftaran perkara di pengadilan niaga; c) Biaya pelaksanaan sita jamina, pengangkatan kurator sementara, dan jaminan yang dianggap wajar oleh pengadilan manakala sita jaminan dikabulkan. Biaya sub a dan c inilah yang tidak pasti besarnya, tergantung pada keadaan, dan inilah juga merupakan kendala bagi pelaksanaan pemberian jaminan perlindungan hukum bagi kreditor sebagaimana diatur oleh Pasal 10 UU No.37/2004.

Besarnya biaya yang tidak pasti tersebut, mengakibatkan kreditor tidak bisa memperhitungkan, berupa hasil yang akan didapatnya manakala menggunakan lembaga hukum kepailitan untuk menyelesaikan perkaranya. Padahal dalam kegiatan ekonomi diperlukan perhitungan yang jelas, atas segala pengeluaran yang mesti dikeluarkan. Oleh karena itu diperlukan suatu pedoman yang mengatur biaya-biaya tersebut, sebagaimana yang telah ditentukan dalam keputusan Menteri Kehakiman Republik Indonesia yang mengatur pedoman besarnya imbalan bagi kurator dan pengurus. Pengaturan tersebut dapat bersifat positif, karena kreditor akan mendapat perlindungan terhadap perhitungan biaya yang sewenang-wenang. Sebelum seseorang kreditor menggunakan lembaga hukum kepailitan, dan permohonan sita jaminan atas harta debitor atau pengangkatan kurator sementara yang bersangkutan akan mendapat gambaran dan perhitungan yang jelas berapa biaya yang harus dikeluarkannya, sehingga dapat diperhitungkan apakah permohonan kepailitan dan jaminan perlindungan hukum atas dirinya, akan memberikan keuntungan yang maksimal atau tidak.

\section{Perbandingan Sistem Perlindungan Hukum Kepailitan di Beberapa Negara}

Perlindungan bagi kreditor adalah merupakan asas hukum yang bersifat universal walaupun berbagai negara menerapkan sistem hukum yang berbeda. Lee AWeng, berpendapat pada umumnya perundang-undangan modern tentang kepailitan dapat diklasifikasikan dalam 
3 (tiga) klasifikasi, yaitu; Latin, Jerman dan Anglo Saxon. ${ }^{18}$ Termasuk dalam klasifikasi Latin antara lain, Perancis, Belgia, daerah kekuasaan Luxemburg, Italia, Portugal, Jepang dan Spanyol pada klasifikasi ini ciri yang teristimewa adalah bahwa kepailitan terbatas untuk pedagang (kooplieden) dan berakibat tidak hormat berlangsung terus, juga sesudah berakhirnya kepailitan hingga rehabilitasi. Tercakup dalam golongan kedua yakni: German, Hungaria, Austria (Dostenrijk), Swedia, Norwegia atau Denmark (Scandinavia). pada klasifikasi ini kepailitan berlaku bagi semua debitor dan yang berakhirnya kepailitan mengakhiri juga segala akibat. Kerap kali diadakan pemilahan undang-undag materiel dan formal. Klasifikasi ketiga adalah Anglo Saxon seperti Inggris, Scotlandia, Irlandia dan Amerika Serikat dimana di negara-negara ini tidak ada pemilahan antara pedagang dan lainnya, pengawasan tidak hanya dilakukan dari hakim, akan tetapi juga dari organ administratif (Board of trade). ${ }^{19}$

Untuk memberi perlindungan hukum bagi kreditor seimbang dengan keadaan debitor, dalam lalu lintas perdagangan yang telah berkembang amat pesat, di Inggris peraturan kepailitan sejak semula tidak dimuat dalam Common Law, akan tetapi dalam Statute Law, sekarang peraturan kepailitan diatur dalam Bankruptcy Act 1914, yang dirubah pada tahun 1926 hingga Insolvency Act $1986 .{ }^{20}$ Dalam peraturan yang baru tersebut, kepailitan tidak berlaku bagi perseroan dan perkumpulan (Vereniging) yang tunduk pada Company Act 1948. ${ }^{21}$ Untuk itu berlaku cara khusus tentang pemberesan dibawah pengawasan hakim (winding up). ${ }^{22}$

Di Amerika Serikat, sistem perlindungan hukum kreditor dalam kepailitan sangatlah diperhatikan dengan sunggu-sungguh dalam perubahan peraturan-peraturan kepailitan yang baru (kini diberlakukan Bankruptcy Reform Act of 1978). Peraturan-peraturan kepailitan tersebut dimaksudkan untuk memberikan perlindungan bagi kreditor dari praktik debitor yang tidak jujur (dishonest) atau kegiatan curang (fraudulent acts of debtors). Kongres Amerika Serikat telah merubah ketentuan tentang kepailitan dalam Bankruptcy Act 1898, secara mendasar dan subtansial. Dalam beberapa amandemennya di tahun 1938 dan akhirnya dengan perubahan ditahun 1978 peraturan kepailitan telah dirubah secara komprehensif dengan membuat perubahan subtansisnya maupun prosedural, sehingga kini menjadi peraturan kepailitan yang modern.

Ronald A. Anderson telah memberikan gambaran pentingnya ketentuan perlindungan bagi kreditor dalam sistem hukum di Amerika Serikat sebagai berikut :

Creditor Protection. Society seeks to protect the rights of creditors and to protect them from dishonest or fraudulent acts of debtors. Initially creditors are protected by the law which declares that contracts are binding and which provides the machinery

18 Lee Aweng, Op.Cit., h. 12.

19 Ibid., h. 13.

20 Ibid.

21 Lee Aweng, dikutip dari David Pelfreman : "Law Relating to Banking Services, Fourth Edition, The MRE Handbook Series, 1998, h. 118.

${ }^{22}$ Ibid., h. 12. 
for the enforcement of contracts, and by the provision of the federal Constitution that prohibits from impairing the obligation of contracts. Further, creditors may compel a debtor to come into bankruptcy. If the debtor has concealed property or transferred it to a friend in order to hide it from creditors, the law permits the creditors to claim the property for the payment of the debts due them. ${ }^{23}$

Perlindungan kreditor. Masyarakat berusaha melindungi hak-hak kreditor dan melindungi mereka dari perbuatan yang tidak jujur atau penipuan dari kreditor. Pada awalnya kreditor dilindungi oleh hukum yang menyatakan bahwa kontrak adalah saling mengikat dan memberikan suatu upaya untuk menjalankan kontrak dan dengan ketentuan Konstitusi Federal yang melarang mengganggu kewajiban kontrak. Selanjutnya, kreditor juga dapat memaksa juga debitor menjadi pailit. Jika debitor memiliki harta kekayaan yang disembunyikan atau dipindahkan kepada seorang temannya untuk menyembunyikannya dari kreditor, maka hukum memungkinkan kreditor mengklaim harta milik tersebut untuk pembayaran hutang-hutangnya.

Suatu perubahan yang besar dalam peraturan kepailitan juga telah dilakukan secara mendasar di Republik Rakyat Cina. Kongres National Rakyat Cina (The National People's Congress-NPC) telah mengesahkan peraturan kepailitan yang baru di tahun 1986. Dalam peraturan kepailitan yang baru tersebut telah membawa perubahan yang besar dan dapat mengembangkan perekonomian Cina sebagaimana telah diakui oleh dunia internasional. Bank Dunia melaporkan bahwa situasi ekonomi di Cina dalam 15 tahun terakhir menyatakan bahwa kepailitan telah menjadi fenomena umum bagi perusahaan milik negara dan swasta sejak pertengahan 19950-an. Dengan pengalaman dalam kepailitan, laporannya menyatakan bahwa Cina memiliki pengetahuan yang cukup untuk memperbaiki dan menyempurnakan sistem kepailitannya sebagai suatu hal yang penting. ${ }^{24}$

Kesadaran akan pentingnya memberi perlindugnan terhadap harta kekayaan (asset) para kreditor yang diinvestasikan di Cina, telah membawa keberhasilan bagi perkembangan ekonomi di Cina. Protected by administrative orders and using coopholes in the current law, many enterprises and individuals have successfully used this gold mine of gobernment money to rid them selves of debt and efven profit trom bankruptcy. ${ }^{25}$ Pemerintah dan rakyat Australia, juga memberi perhatian yang penuh atas pentingnya peraturan kepailitan diterapkan sebaikbaiknya dan ditangani secara khusus oleh Federal Court.

Sistem hukum ketentuan perundangan-perundangan di Australia, dapat diketahui dengan baik apabila dipahami bagaimanakah peraturan perundang-undangan Australia dibuat. Di Australia, peraturan perundang-undangan terdiri dari: 1) Undang-Undang yang dibuat dan disahkan oleh Parlemen Federal yang bertindak dalam raung lingkup kekuasaan yang dimilikinya berdasarkan konstitusi Australia, bersama dengan peraturan perundang-

23 Ronald A. Anderson, Business Law, Elevanth Edition, Cincinnalis West Chicago, Dalas: South Western Publishing, Co, 1980, h. 22.

24 China International Business, May 2002, h.30

25 Ibid, h. 71. 
undangan delegasi dan peraturan perundang-undangan bawahan yang dibuat sebagai peraturan pelaksanaan dari Undang-Undang tersebut; 2) Ordonansi dibuat sesuai dengan masing-masing wilayah (negara bagian), bersama dengan peraturan perundang-undangan delegasi atau peraturan pelaksanaan dari ordonansi tersebut; 3) Undang-undang yang dibuat oleh Parlemen negara-negara bagian dan dewan perwakilan Nother Territory, Australian Capital Territory dan Norfolk Island, bersama dengan peraturan perundangan delegasi atau peraturan perundangan pelaksanaan dari undang-undang tersebut; 4) Sistem hukum Common Law Australia, merupakan sistim hukum yang dikembangkan dari sistim hukum Common Law Inggris yang lebih jauh lagi telah diinterpretasikan dan dimodifikasi oleh Pengadilan Australia. ${ }^{26}$

Konstitusi tidak memberikan parlemen federal kekuasaan untuk membuat undangundang dalam seluruh hal. Lebih jauh lagi, konstitusi menetapkan daftar permasalahan yang merupakan kewenangan parlemen federal. Hampir semua kewenangan ini termuat pada Pasal 51 dan Pasal 52 Konstitusi, yang mencakup perpajakan, pertanahan, urusan luar negeri, lintas negara bagian, perdagangan nasional, masalah asing, perdagangan dan perusahaan keuangan, perkawinan dan perceraian, imigrasi, kepailitan dan arbitrase industri negara bagian.Saat ini masalah kepailitan di Australia diputuskan menjadi kewenangan Pengadilan Federal Australia. Pengadilan Federal Australia didirikan menurut undang-undang tahun 1976 tentang Pengadilan Federal Australia, dan mulai melaksanakan kewenangannya pada tanggal 1 Februari 1977.

Selain masalah kepailitan, Pengadilan Federal juga diberi kewenangan sebagai pengadilan tingkat pertama oleh berbagai undang-undang yang dibuat oleh parlemen federal antara lain termasuk hukum perusahaan, perburuhan, perpajakan dan praktik-praktik perdagangan.Prinsip dasar memberi perlindungan hukum kreditor, secara seimbang dengan kepentingan debitor juga menjadi perhatian dalam pembaruan hukum kepailitan di Australia. Ada dua tujuan undang-undang kepailitan yaitu untuk mengembalikan dana kepada kreditor dan untuk merehabilitasi kepailitan. Dalam mencapai tujuan ini, undang-undang kepailitan modern haruslah memuat beberapa prinsip berikut: 1) Administrasi imparsial dan efisien untuk mendistribusikan harta milik debitor kepada kreditornya; 2) Proses administratif dimana debitor dan kreditor dapat ikut serta dengan kemungkinan terjadinya keterlambatan dan pengeluaran yang kecil; 3) Cara yang lebih sesuai dari pengumpulan atau perolehan harta milik debitor dapat diterapkan terhadap pembayaran hutang dan kewajibannya; 4) Perlindungan kepentingan umum dengan menghukum penipu dan dengan membebaskan debitor oleh ketidak beruntungannya. ${ }^{27}$ Dalam praktik perkara kepailitan di Ausralia dipergunakan ketentuan Bankruptcy Legislation Amandement Act 1996, yang merupakan

\footnotetext{
${ }^{26}$ Australian Legal Resources International, "Government Sector Linkages Program (65LP II) Australian Legal System", Sydney NSWAustralia: ALRI, p. 1.

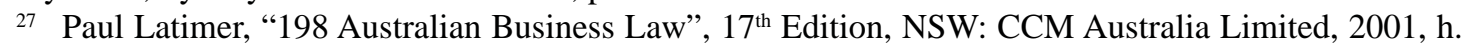
885.
} 
amandemen dari the Bankruptcy Act 1966 dan diberlakukan sejak 16 Desember 1966. Beberapa prinsip dasar penting dalam perubahan undang-undang kepailitan tersebut yaitu: 1) Memberikan layanan bagi kepailitan dan debitor yang pailit di dalam ITSA di kejaksaan Australia. Amandemen tahun 1996 dirancang untuk mengefektifkan abolisi dari jabatan pencatat kepailitan dan pembagian fungsi diantara inspektur jenderal di dalam bidang kepailitan, penerima resmi, pengawas kepailitan dan pengadilan federal; 2) Menyerahkan proses peradilan kepailitan kepada pengadilan federalAustralia, sesuai dengan skemajurisdiksi yang ada; 3) Modernisasi dan kemudahan pelaksanaan dalam kaitannya dengan pengalihan harta benda sebelum kepailitan; 4) Memuat beberapa rencana pembagian pendapatan yang telah diperbaiki; 5) Memiliki bagian IX yang baru untuk undang-undang yang menciptakan perjanjian dengan kreditor sebagai alternatif terhadap kepailitan; 6) Memperbaiki susunan pendaftaran dan catatan tugas dan kekuasaan pengawas: 7) Kemudahan untuk pembentukan indeks kepailitan pribadi nasional yang ditetapkan atas dasar perundang-undangan serta menjadi subjek bagi parlemen federal. ${ }^{28}$

\section{Kesimpulan}

Sistem penjatuhan sita jaminan perlindungan hukum kreditor dalam kepailitan sebelum penjatuhan putusan pailit yang operasionalnya mengacu kepada ketentuan yang diatur dalam Undang-Undang No. 37 Tahun 2004 tentang Kepailitan Dan PKPU, pengaturannya terlalu sederhana dan kurang lengkap atau terperinci, sehingga menimbulkan bias dalam penapsiran dan sangat sulit dilaksanakan dalam praktik penegakan hukum di pengadilan niaga.

Maksud lembaga kepailitan sebenarnya adalah agar semua harta debitor yang dinyatakan pailit disita untuk dilelang, dan hasilnya dibagikan menurut skala prioritas dan bagi tagihan yang konkuren dibagi seimbang dengan tagihan masing-masing kreditor. Tugas dari kurator (Balai Harta Peningalan) di bawah pengawasan hakim pengawas adalah menyeleksi tagihan dan melelang harta debitor, untuk dibagikan kepada semua kreditor. Namun, permasalahan akan muncul manakala selama proses kepailitan berlangsung debitor melakukan perbuatan tidak jujur atau praktik curang dengan sengaja mengalihkan harta bendanya sehingga dapat merugikan kreditor.

Dalam rangka melindungi kreditor dari praktik curang (tidak jujur) debitor tersebut, dalam Pasal 10 Undang-Undang No. 37 Tahun 2004 tentang Perubahan Atas UndangUndang Tentang Kepailitan diatur bahwa kreditor selama permohonan pernyataan pailit belum ditetapkan dapat mengajukan permohonan kepada pengadilan, untuk: 1) Meletakkan sita jaminan terhadap sebagian atau seluruh kekayaan debitor; atau 2) Menunjuk kurator sementara untuk mengawasi pengelolaan usaha debitor dan pembayaran kepada kreditor, pengalihan atau pengagunan kekayaan debitor yang dalam rangka kepailitan. Dalam praktik penegakan hukum ternyata ketentuan yang dimaksudkan untuk melindungi kepentingan

\footnotetext{
28 Ibid, h. 86.
} 
kreditor tersebut, sejak pengadilan niaga dibentuk dan didirikan pada 20 Agustus 1998) sampai dengan Agustus 2006, ketentuan dimaksud tidak pernah diterapkan. Di kalangan praktisi hukum seperti: hakim niaga, penasihat hukum dan kurator terdapat pandangan bahwa ketentuan dimaksud sangat sulit dilaksanakan karena terbatasnya waktu pemeriksaan di pengadilan niaga. Selain itu ketentuan yang mengatur jaminan perlindungan hukum tersebut tidak rinci dan jelas (bias), serta biaya yang diperlukan selama proses kepailitan berlangsung dirasakan relatif besar dan tidak ada patokan (ukuran) yang dapat diprediksi dengan tepat. Akan tetapi, semua praktisi hukum tersebut berpendapat bahwa lembaga jaminan untuk melindungi kepentingan kreditor selama proses kepailitan berlangsung masih diperlukan.

Pemerintah perlu segera mengeluarkan peraturan pemerintah yang mengatur tentang eksistensi, lingkup dan kewenangan pengadilan niaga sebagai pengadilan dalam lingkungan peradilan umum, yang memeriksa dan mengadili perkara-perkara khuus di bidang perniagaan, agar tidak menimbulkan bias dalam menafsirkan tugas dan wewenang (yurisdiksi) pengadilan niaga tersebut. Jaminan perlindungan hukum bagi kreditor dalam perkara kepailitan telah menjadi asas hukum yang bersifat universal, sehingga hampir seluruh negara dalam pembaharuan hukum kepailitannya memperhatikan hal tersebut untuk mengembangkan perekonomiannya. Oleh karena itulah, dalam Undang-Undang Kepailitan mendatang, pengaturan lembaga hukum perlindungan bagi kreditor dan kepailitan harus lebih dijelaskan dan diatur dengan detail dan rinci serta segera dibuat peraturan pelaksanaannya agar ketentuan tersebut dapat secara efektif berlaku di masyarakat. Terhadap perkara yang merupakan kelanjutan dari proses penjatuhan pailit, dan ataupun perkara yang berhubungan dengan perkara kepailitan sebaiknya diperiksa dan diadili oleh pengadilan niaga, bukan di pengadilan negeri, agar tercapai penyelesaian sengketa secara adil, cepat, terbuka, dan efektif.

\section{Daftar Bacaan}

Buku

Anderson, Business Law, Eleventh Edition, Cicinalis West Chigago, Dallas, South Western Publishing, Co, 1980.

Ashofa, Metode Penelitian Hukum, Jakarta, Rineka Cipta, 1996.

A Weng, Tinjauan Pasal Demi Pasal FV (Faillsements Verordening) S. 1905 No.217 jo S.1905 No.348 jo PERPU No. 11998 Dan Undang-Undang No.4 Tahun 1998, Medan, 2000.

Badrulzaman, Perjanjian Kredit Bank, Bandung, Alumni, 1980.

Aneka Hukum Bisnis, Bandung, Alumni, 1994.

KUH Perdata Buku III Hukum Perikatan dengan Penyelesaian, Bandung, Alumni, 1995. 
Bintang, Sanusi, Dahlan, Pokok-pokok Hukum Ekonomi Dan Bisnis, Bandung,Gelora Aditya Bakti, 2000.

Dennis Rose, Australian Bankrupcy Law, Tenth Edition, The Law Book Company Ltd, 1994.

Fuady, Hukum Pailit 1998 Dalam Teori Dan Praktek, Bandung, Citra Aditya Bakti, 1999.

Friedmann, Teori Dan Filsafat Hukum, Jakarta, Rajawali Press, 1990.

Garner, (Ed), Black's Law Dictionary, Deluxe-Seventh Edition, Unites Stated of America, Weet Group, Dallas Texas, 2000.

Gautama, Komentar Asas Peraturan Kepailitan Baru1998, Bandung, Citra Aditya Bakti, 1998.

Gandasubrata, Renungan Hakim, Jakarta, Mahkamah Agung RI, 1998.

Gijssel and van Hoecke, Wat is Rechtheorie?,Antwerpen, Kluwer, 1982

Latimer, Australian Business Law, 17 $7^{\text {th }}$ Edition, NSW,CCM Australian Limited Sydney, 2001.

Kelsen, What Is Justice, Law, And Politics in the Mirror for Science, Barkeley and Los Angeles: University Of California Press, 1957

Kamil, Filsafat Kebebasan Hakim, Jakarta, Kencana Prenada Media Group,2012.

Marzuki, Pengantar Ilmu Hukum, Edisi Revisi, Jakarta, Kencana Prenada Media Group, 2008.

Mahkamah Agung RI, Makalah Para Pakar Yang Berkaitan Dengan Undang-ndang No.4 Tahun 1998 jo PERPU No.1 Tahun 1998 tentang Kepailitan, MARI, Jakarta, 1999.

---------, Pedoman Pelaksanaan Administrasi Penyelesaian Perkara Pada Pengadilan Niaga, MARI, 1999.

Mertokusumo, Bab-bab Tentang Penemuan Hukum, Yogyakarta, Liberty, 1993.

--------, Hukum Acara Perdata Indonesia, Yogyakarta,Liberty, 1981.

Rasjidi dan Rasjidi, Dasar-Dasar Filsafat dan Teori Hukum, Cetakan Kedelapan, Bandung Penerbit Citra Aditya Bakti, 2001.

Salomon, Philosophy - Problem and Perspectives, New York,Harcourt Brace Jovanovich, 1981.

Sidharta, Buku Terjemahan Meuwissen, Tentang Pengembangan Hukum, Ilmu Hukum, Teori Hukum, dan Filsafat Hukum, Bandung, Refika Aditama, 2007.

Shubhan, Hukum Kepailitan Prinsip, Norma, dan Praktek di Peradilan,Prenada Media 
Group), Jakarta, 2008.

Sunggono, Metodologi Hukum, Jakarta, Raja Grafindo Persada, 1998.

Situmorang, Victor dan Sukarso, Pengantar Hukum Kepailitan di Indonesia, Jakarta,Rineka Cipta, 1994.

Sumantoro (Penyunting), Hukum Ekonomi, Jakarta, UI Press, 1986.

Sutantio, et.al., Hukum Acara Perdata Dalam Teori Dan Praktek, Bandung, Alumni, 1985.

Soemitro, Metodologi Penelitian Hukum Dan Jurimetri, Jakarta, Ghalia Indonesia, 1990.

Utrecht dan Djondang, Pengantar Dalam Hukum Indonesia, Jakarta, Sinar Harapan, 1989.

Waluyo, Hukum Kepailitan Dan Penundaan Kewajiban Pembayaran Utang, Bandung, Mandar Maju, 1999.

Yani dan Widjaja, 1999, Seri Hukum Bisnis Kepailitan, Jakarta, RajaGrafindoPersada, 1999.

Yulius, et.al., Kamus Baru Bahasa Indonesia, Surabaya, Usaha Nasional, 1988.

\section{Makalah}

Djohansah, "Hukum Asuransi Yang Berkaitan Dengan Pelaksanaan Hukum Kepailitan Nasional”, disampaikan pada Pendidikan Dan Pelatihan Teknis Fungsional Peningkatan Profesionalisme Bagi Hakim Pengadilan Niaga, di Jakarta, 2001.

Ginting, "Usulan Penelitian Kedudukan Kreditor Separatis Dalam Perkara Kepailitan”, USU, Medan, 2002.

Hariningsih, "Perbandingan Pengaturan Masalah Kepailitan Dalam PERPU No.1 Tahun 1998 jo Undang-Undang No. 4 Tahun 1998 Dengan Rancangan Undang-Undang Tentang Kepailitan Dan Penundaan Kewajiban Pembayaran Utang”, Lokakarya Mengenai Rancangan Perubahan Undang-Undang Kepailita, di USU, Medan, 7 Desember 2001.

Kesowo, “PERPU No.1 Tahun 1998, Latar Belakang Dan Arahnya”, Makalah Calon Hakim Pengadilan Niaga, disampaikan dalam pelatihan Calon Hakim Niaga, di Medan, 1999.

Lotulung, "Kedudukan Tugas Dan Kewenangan Pengadilan Niaga”, Bahan Ceramah Pelatihan Calon Hakim Niaga, di Medan, MARI, 1999.

Marzuki, Peran Hakim Dalam Penemuan Hukum, Seminar Nasional, Universitas Airlangga, Surabaya, 22 September 2012.

Manahan, "Syarat-syarat Pernyataan Pailit Menurut Pasal 1 ayat (1) Undang-Undang No- 
mor 4 Tahun 1998 dan Penerapan oleh Peradilan Niaga', USU, Medan, 2001.

Perdamaian, "Makalah Syarat-syarat Pengajuan Kepailitan Dan Kelemahan Hukum Acara Kepailitan Dalam Praktek Pengadilan Niaga”, Forum Diskusi Hukum, Medan, 2001.

Setiawan, "Kepailitan Konsep-Konsep Dasar Serta Pengertiannya”, Makalah Pelatihan Calon Hakim Pengadilan Niaga, MARI, Jakarta, 1998.

Sidharta, Penemuan Hukum Dalam Kajian Filsafat Hukum, Seminar Nasional, Universitas Airlangga, Surabaya, 22 September 2012.

Simanjuntak, "Kemandirian Tugas Kurator Dalam Melakukan Pengurusan Dan Pemberesan Dalam Kepailitan", KumpulanMakalah, Seminar sehari Revitalisasi Tugas Dan Wewenang Kurator/Pengurus, Hakim Pengawas \& Hakim Niaga Dalam Rangka Kepailitan, Jakarta, 16 Oktober 2003, Cetakan Pertama, Januari 2004.

Sutadi, "Hukum Acara Pada Pengadilan Niaga”, Makalah Pelatihan Teknik Yustisial Bagi Hakim Niaga, MARI, Malang, 1999.

Yuska, "Penyanderaan Dalam Rangka Penegakan Hukum Pajak Yang Berperspektif Hak Asasi Manusia”'Disertasi, Program Doktor Ilmu Hukum, Fakultas Hukum, Universitas Airlangga, Surabaya. 